\title{
Pengaruh Perputaran TATO, Rasio Lancar dan DAR Atas ROE pada Perusahaan Industri Barang Konsumsi di BEI 2015 - 2019
}

\section{The Effect of TATO, Current Ratio and DAR Rounding on ROE on Consumption Goods Industry Companies in IDX 2015 - 2019}

\author{
Sufika Sary \\ Departemen Manajemen, Fakultas Ekonomi, Universitas Prima Indonesia, Medan \\ e-mail: sufikasary6@gmail.com \\ Laura Denita* \\ Departemen Manajemen, Fakultas Ekonomi, Universitas Prima Indonesia, Medan \\ e-mail: laura.denita.ld13@gmail.com \\ Aprilda \\ Departemen Manajemen, Fakultas Ekonomi, Universitas Prima Indonesia, Medan \\ e-mail: aprildaliuu@gmail.com \\ Cynthia \\ Departemen Manajemen, Fakultas Ekonomi, Universitas Prima Indonesia, Medan \\ e-mail: cynthialui1810@gmail.com
}

\begin{abstract}
The purpose of this analysis is to explain how the impact of TATO, Current Ratio, DAR on ROE on the consumer goods industry on the IDX during 2015-2019. The total population is 58 with 26 companies as the sample. Techniques and data analysis in this study using purposive sampling, multiple linear regression analysis and classical hypothesis testing. This can be seen from the results of the study that simultaneously TATO, Current Ratio, DAR have an effect but not significant on ROE in consumer goods industrial companies listed on the IDX 2015-2019 with the results $F_{\text {count }}>F_{\text {table }}(7,760>2,68)$. Partially, TATO has a significant effect on ROE, with the result $t_{\text {count }}\left\langle t_{\text {table }}(3,753\rangle\right.$ 1,97897). Current ratio has no and insignificant effect on ROE while DAR has no significant effect on ROE. The result of adjusted R-squared 0.136 or the coefficient of determination of $13,6 \%$ percent of the dependent variable ROE which can be explained by the independent variables TATO, Current Ratio, and DAR.
\end{abstract}

Keywords: Current Ratio, DAR, ROE, TATO.

\begin{abstract}
ABSTRAK
Maksud dari penganalisian ini adalah untuk menjelaskan bagaimana dampak TATO, Rasio Lancar, DAR atas ROE pada industri barang konsumsi di BEI selama 2015-2019. Jumlah populasi sebanyak 58 dengan 26 perusahaan sebagai sampel. Teknik dan analisa data dalam penelitian ini menggunakan purposive sampling, analisis regresi linier berganda dan pengujian hipotesis klasik. Hal ini dapat dilihat dari hasil penelitian bahwa secara simultan TATO , Rasio Lancar, DAR memiliki pengaruh tetapi tidak signifikan terhadap ROE pada perusahaan industri barang konsumsi yang tercatat di BEI 2015-2019 dengan hasil $F_{\text {hitung }}>F_{\text {tabel }}(7,760>2,68)$. Secara parsial, TATO memiliki pengaruh signifikan atas ROE, dengan hasil thitung $<t_{\text {tabel }}(3,753>1,97897)$. Rasio Lancar tidak memiliki pengaruh serta tidak signifikan pada ROE sedangkan DAR tidak memilik pengaruh serta signifikan atas ROE. Hasil adjusted $R$-squared 0,136 atau koefisien determinasi sebesar 13,6 persen dari variabel dependen ROE yang dapat diterangkan oleh variabel independen TATO, Rasio Lancar, serta DAR.
\end{abstract}

Kata kunci: Current Ratio, DAR, ROE, TATO. 


\section{PENDAHULUAN}

Seiring berkembangnya perekonomian Indonesia, maka semakin bertambah juga perusahaan-perusahaan yang berdiri diantaranya ialah industri barang konsumsi. Setiap perusahaan yang berdiri pasti memiliki tujuan yang sama yakni untuk memperoleh keuntungan dan mempertahankan perusahaannya di masa depan. Tetapi tidak sedikit juga perusahaan yang mengalami kebangkrutan karena tidak dapat mengatasi masalah-masalah yang terjadi di dalam perusahaannya. Dalam memperoleh keuntungan yang maksimal, sebuah perusahaan harus dapat mengelola sumber daya dengan benar, terutama dalam mengelola aset perusahaan.

Dengan masalah-masalah yang terjadi pada setiap perusahaan, membuat perusahaan semakin memperkuat kinerja keuangannya agar dapat tidak mengalami kerugian. Baik ataupun buruknya kinerja keuangan suatu perusahaan dapat dinilai dengan memakai rasio profitabilitas. Fungsi profitabilitas merupakan untuk mengukur keahlian perusahaan mendapatkan laba dalam hubungannya dengan penjualan, total aktiva dengan menghasilkan keuntungan dengan ROE, dimana perusahaan menggunakan rasio tersebut untuk mengetahui seberapa daya guna sebuah perusahaan secara merata. Dengan rasio ini, kita bisa melihat apakah perusahaan ini efektif dalam menggunakan aktivanya dalam aktivitas operasional perusahaannya.

Kinerja perusahaan yang baik harus dapat mengelola penjualan, aktiva lancar dan juga utangnya dengan baik agar dapat mencapai laba yang diinginkan. Persaingan dapat bermula dari penjualan, perusahaan dengan jumlah penjualan yang banyak tentu saja akan meningkatkan jumlah laba yang diperoleh, apabila penjualan menurun maka laba yang diperoleh juga menurun. Aktiva lancar dan total utang yang tinggi/rendah tentu saja juga akan mempengaruhi laba bersih sebuah perusahaan.

Dari 58 jumlah perusahaan yang terdaftar para peneliti menemukan beberapa perusahaan yang bermasalah di laporan keuangannya, ada perusahaan yang mengalami kenaikan pada penjualannya namun labanya menurun atau sebaliknya. Ada juga perusahaan yang jumlah aktiva lancarnya meningkat namun labanya menurun. Ada juga yang utangnya meningkat namun labanya juga meningkat. Berikut ini adalah data permasalahan yang dihadapi industri barang konsumsi beberapa tahun terakhir:

Tabel 1. Data-data keuangan perusahaan industri barang konsumsi di BEI Periode 2015-2019 (dalam Rupiah)

\begin{tabular}{|c|c|c|c|c|c|}
\hline $\begin{array}{c}\text { Nama } \\
\text { Perusahaan }\end{array}$ & Tahun & Penjualan & Aktiva Lancar & Total Utang & EAT \\
\hline \multirow{5}{*}{$\begin{array}{l}\text { PT. Handjaya } \\
\text { Mandala } \\
\text { Sampoerna, } \\
\text { Tbk (HMSP) }\end{array}$} & 2015 & 89.069 .306 .000 .000 & 29.807 .330 .000 .000 & 5.994 .664 .000 .000 & 10.363 .308 .000 .000 \\
\hline & 2016 & 95.466 .657 .000 .000 & 33.647 .496 .000 .000 & 8.333 .263 .000 .000 & 12.762.229.000.000 \\
\hline & 2017 & 99.091 .484 .000 .000 & 34.180 .353 .000 .000 & 9.028 .078 .000 .000 & 12.670 .534 .000 .000 \\
\hline & 2018 & 106.741 .891 .000 .000 & 37.831 .483 .000 .000 & 11.244.167.000.000 & 13.538 .418 .000 .000 \\
\hline & 2019 & 106.055 .176 .000 .000 & 41.697.015.000.000 & 15.223.076.000.000 & 13.721 .513 .000 .000 \\
\hline \multirow{7}{*}{$\begin{array}{l}\text { PT. Indofood } \\
\text { CBP Sukses } \\
\text { Makmur, Tbk } \\
\text { (ICBP) }\end{array}$} & 2015 & 31.741 .094 .000 .000 & 13.961.500.000.000 & 10.173.713.000.000 & 2.923 .148 .000 .000 \\
\hline & 2016 & 34.466 .069 .000 .000 & 15.571 .362 .000 .000 & 10.401 .125 .000 .000 & 3.631 .301 .000 .000 \\
\hline & 2017 & 35.606 .593 .000 .000 & 16.579 .331 .000 .000 & 11.295 .184 .000 .000 & 3.543 .173 .000 .000 \\
\hline & 2018 & 38.413 .407 .000 .000 & 14.121 .568 .000 .000 & 11.660.003.000.000 & 4.658 .781 .000 .000 \\
\hline & 2019 & 42.296.703.000.0000 & 16.624 .925 .000 .000 & 12.038.210.000.000 & 5.360 .029 .000 .000 \\
\hline & 2015 & 3.485 .733 .830 .354 & 1.253 .019 .074 .345 & 845.932 .695 .663 & 106.549 .446 .980 \\
\hline & 2016 & 4.115.541.761.173 & 1.103.865.252.070 & 538.044 .038 .690 & 249.697.013.626 \\
\hline \multirow{3}{*}{$\begin{array}{l}\text { PT.Wilmar } \\
\text { Cahaya } \\
\text { Indonesia, } \\
\text { Tbk (CEKA) }\end{array}$} & 2017 & 4.257.738.486.908 & 988.479.957.549 & 489.592 .257 .434 & 107.420 .886 .839 \\
\hline & 2018 & 3.629.327.583.572 & 809.166 .450 .672 & 192.308.466.864 & 92.649 .656 .775 \\
\hline & 2019 & 3.120 .937 .098 .980 & 1.067.652.078.121 & 261.784 .845 .240 & 215.459 .200 .242 \\
\hline
\end{tabular}

Bersumber pada Tabel 1 dapat dilihat bahwa PT. Handjaya Mandala Sampoerna pada tahun 2017 mengalami kenaikan pada penjualan namun laba bersih mengalami penurunan akan tetapi pada tahun 2019 penjualannya mengalami penurunan namun laba bersih mengalami kenaikan. Aktiva lancar pada tahun 2016, 2018 dan 2019 mengalami kenaikan yang disertai dengan kenaikan laba bersih. Total utang pada tahun 2016, 2018, dan 2019 mengalami kenaikan akan tetapi laba bersih juga mengalami kenaikan.

Jurnal Manajemen dan Organisasi (JMO),

Vol. 12 No. 2 Agustus 2021 Hal. 146-155 
Pada PT. Indofood CBP Sukses Makmur pada tahun 2017 mengalami kenaikan pada penjualan namun laba bersih mengalami penurunan. Aktiva lancar pada tahun 2016 dan 2019 mengalami kenaikan dan laba bersih juga mengalami kenaikan. Total utang pada tahun 2016, 2018, dan 2019 mengalami kenaikan akan tetapi laba bersih juga mengalami kenaikan. Pada PT. Wilmar Cahaya Indonesia pada tahun tahun 2017 mengalami kenaikan pada penjualan namun laba bersih mengalami penurunan akan tetapi pada tahun 2019 penjualannya mengalami penurunan namun laba bersih mengalami kenaikan. Aktiva lancar pada tahun 2017 dan 2018 mengalami penurunan dan laba bersih juga mengalami penurunan, sedangkan aktiva lancar pada tahun 2019 mengalami kenaikan yang disertai dengan penaikan laba bersih. Total utang pada tahun 2017 mengalami penurunan dan laba bersih juga mengalami penurunan akan tetapi pada tahun 2019 total utang mengalami kenaikan yang disertai dengan kenaikan laba bersih.

\section{METODE PENELITIAN}

\section{Populasi dan Sampel Penelitian}

Menurut Sugiono (2015), populasi merupakan gabungan dari beberapa objek atau subjek dengan memiliki ciri serta karakteristik tertentu yang ditentukan oleh peneliti untuk mempelajari dan menyimpulkan permasalahannya. Sugiono (2015) menyatakan, sampel adalah unsur jumlah dan karakteristik atas populasi. Penelitian memerlukan tata cara purposive sampling yang artinya cara pengumpulan sampel dengan pertimbangan khusus serta pengutipan data disesuaikan dengan standar yang telah ditetapkan. Adapun kategorinya adalah: (1) Perusahaan industri barang konsumsi yang tercatat pada BEI 2015-2019, (2) Perusahaan sektor industri barang konsumsi yang mempublikasikan laporan keuangannya secara berturut-turut pada BEI 2015-2019, (3) Perusahaan industri barang konsumsi yang net income-nya bernilai positif yang tercatat pada BEI 2015-2019. (4) Perusahaan industri barang konsumsi yang mengajikan laporan dalam satuan Rupiah. Berdasarkan beberapa kategori diatas, perusahaan yang dijadikan sampel berjumlah 26. Penelitian ini mengambil 5 tahun, sehingga 26 x $5=130$. Sampel yang digunakan dalam penelitian ini berjumlah 130 .

\section{Definisi Operasional Variabel Penelitian}

Total Asset Turnover (TATO)

TATO merupakan rasio yang dipakai guna mengetahui kemampuan manajemen mengelola investasi (aset) secara keseluruhan guna menghasilkan penjualan, Syaifullah (2014).

Menurut Sukamulja (2019), cara menghitung total asset turnover adalah:

$\underline{\text { Rasio Lancar }}$

$$
\text { TATO }=\frac{\text { Penjualan }}{\text { Total Aset }}
$$

Rasio lancarmerupakan rasio yang umumnya dipakai guna mengetahui efektivitas perusahaan dalam menangani kewajiban jangka pendek yang akan habis waktunya dalam satu tahun, Murhadi (2013).

Menurut Sulindawati et al. (2018), cara menghitung current ratio adalah:

\section{Dept to Asset Ratio (DAR)}

$$
\text { CurrentRatio }=\frac{\text { AktivaLancar }}{\text { UtangLancar }} \times 100 \%
$$

Rasio ini menerangkan seberapa banyak hutang yang dapat ditutupi oleh aset lebih besar rasionya lebih aman. Atau dapat dikatakan beberapa jumlah utang dengan aktiva agar keamanan jumlah utang terhadap aktiva lebih kecil, Harahap (2015).

Menurut Hery (2018), cara menghitung debt to assets ratio adalah:

$$
\text { RasioUtang }=\frac{\text { TotalUtang }}{\text { TotalAset }}
$$




\section{Return on Equity (ROE)}

ROE merupakan rasio yang dipakai guna mengukur seberapa efisiensi perusahaan untuk mendapatkan laba yang dapat digunakan oleh pemilik saham perusahaan (Syahyunan, 2013).

Menurut Fahmi (2017), cara menghitung return on equity adalah:

\section{Teknik Analisa Data}

$$
R O E=\frac{\text { Earning After Tax (EAT) }}{\text { Shareholder's Equity }}
$$

\section{Uji Asumsi Klasik}

Metode analisis statistik merupakan metode analisa data yang menggunakan bantuan program SPSS. Bagian-bagian dari uji asumsi klasik adalah: uji normalitas, uji multikolinieritas, uji autokorelasi, uji heteroskedastisitas.

a. Pengujian Normalitas

Pengujian normalitas bertujuan menyelidiki apakah dalam model regresi, variabel pengganggu ataupun residual mempunyai pendistribusian normal (Ghozali, 2016).

b. Pengujian Multikolinieritas

Pengujian multikolinieritas bertujuan menyelidiki apakah model regresi memiliki terdapatnya korelasi antar variabel leluasa (Ghozali, 2016).

c. Pengujian Autokorelasi

Uji autokorelasi bertujuan menyelidiki apakah didalam model regresi linear terkandung korelasi serta kesalahan gangguan di periode $t$ dengan kesalahan gangguan di periode $\mathrm{t}-1 \mathrm{yang}$ pada awalnya (Ghozali, 2016).

d. Pengujian Heteroskedastisitas

Uji heteroskedastisitas bertujuan menyelidiki apakah dalam model regresi terjalin perbandingan varians dari residual satu peninjauan ke peninjauan lainnya (Ghozali, 2016).

\section{Pengujian Hipotesis}

a. Pengujian Koefisien Determinasi $\left(\mathrm{R}^{2}\right)$

Bagi Ghozali (2016:95), koefisien determinasi $\left(\mathrm{R}^{2}\right)$ digunakan untuk mengetahui seberapa besar kemampuan model dalam menjelaskan variasi variabel dependen.

b. Pengujian Secara Simultan (Uji F)

Bagi Ghozali (2016:96), uji F digunakan untuk menunjukkan apakah variabel independen memiliki pengaruh terhadap variabel terkait. Adapun bentuk pengujiannya sebagai berikut :

$\mathrm{H}_{0}: \beta_{1} \beta_{2} \beta_{3}=0$ berarti TATO, rasio lancar, dan DAR secara simultan tidak mempunyai pengaruh atas ROEdi perusahaan industri barang konsumsi pada BEI selama 2015 sampai 2019. $\mathrm{H}_{1}: \beta_{1} \beta_{2} \beta_{3} \neq 0$ berarti TATO, rasio lancar, dan DAR secara simultan mempunyai pengaruh atas ROE di perusahaan industri barang konsumsi pada BEI selama 2015 sampai 2019.

Dalam pengkajian ini nilai $F_{\text {hitung }}$ dibanding dengan $F_{\text {tabel }}$ dengan tingkatan keyakinan adalah $(\alpha=0,05)$. Kriteria pengambilan keputusan pada uji $\mathrm{F}$ sebagai berikut:

$\mathrm{H}_{0}$ diterima apabila $\mathrm{F}_{\text {hitung }} \leq \mathrm{F}_{\text {tabel }}$ pada $\alpha=0,005$

$\mathrm{H}_{1}$ diterima apabila $\mathrm{F}_{\text {hitung }} \geq \mathrm{F}_{\text {tabel }}$ pada $\alpha=0,005$

c. Pengujian Secara Parsial (Uji t)

Menurut Ghozali (2016), uji t digunakan untuk menerangkan bagaimana besarnya pengaruh satu variabel independen secara individual dalam menjelaskan variabel independen. Berikut adalah cara pengujiannya:

$\mathrm{H}_{0}: \beta_{1} \beta_{2} \beta_{3}=0$ berarti TATO, rasio lancar, dan DAR secara parsial tidak memiliki pengaruh atas ROEdi perusahaan industri barang konsumsi pada BEI selama 2015 sampai 2019.

$\mathrm{H}_{1}: \beta_{1} \beta_{2} \beta_{3} \neq 0$ berarti TATO, rasio lancar, dan DAR secara parsial memiliki pengaruh atas ROEdi perusahaan industri barang konsumsi pada BEI selama 2015 sampai 2019.

Dalam pengkajian ini nilai thitung dibandingin bersama $t_{\text {tabel }}$ dengan tingkat kepercayaan adalah $(\alpha=0,05)$. Etika pengutipan keputusan terhadap uji t sebagai berikut:

$\mathrm{H}_{0}$ diterima apabila $\mathrm{t}_{\text {hitung }} \leq \mathrm{t}_{\text {tabel }}$ pada $\alpha=0,005$

$\mathrm{H}_{1}$ diterima apabila $\mathrm{t}_{\text {hitung }} \geq \mathrm{t}_{\text {tabel }}$ pada $\alpha=0,005$

Jurnal Manajemen dan Organisas 


\section{HASIL DAN PEMBAHASAN}

\section{Hasil Statistik Deskriptif}

Tabel 2.Statistik Deskriptif

\begin{tabular}{|c|c|c|c|c|c|}
\hline \multicolumn{6}{|c|}{ Descriptive Statistics } \\
\hline & $\mathrm{N}$ & Minimum & Maximum & Mean & Std. Deviation \\
\hline TATO & 130 & ,484 & 3,105 & 1,21369 &, 518196 \\
\hline $\mathrm{CR}$ & 130 & ,078 & 9,277 & 2,93118 & 1,916194 \\
\hline DAR & 130 & 071 & ,744 & ,36636 &, 174405 \\
\hline ROE & 130 & 019 & 2,245 & ,24633 & ,339384 \\
\hline Valid N (listwise) & 130 & & & & \\
\hline
\end{tabular}

Dari tabel 1 ditemukan bahwa nilai min, max, mean dan std deviation dari variabel-variabel bebas, yang meliputi TATO $\left(\mathrm{x}_{1}\right)$, Rasio Lancar $\left(\mathrm{x}_{2}\right)$, DAR $\left(\mathrm{x}_{3}\right)$ dan ROE (Y) yang merupakan variabel terikat dengan penjelasan:

1. TATO $\left(\mathrm{X}_{1}\right)$ memiliki sampel sebanyak 130 , dengan angka minimum berbilang 0,484 yang didapati PT.MERK di 2018. Angka maximum berbilang 3,105 yang didapati PT.WCI di 2018, sedangkan angka mean TATO industri barang konsumsi adalah 1,21369 dengan std deviation sebesar 0,518196 .

2. Rasio Lancar $\left(\mathrm{X}_{2}\right)$ memiliki sampel sebanyak 130, dengan angka minimum berbilang 0,078 yang didapati PT.MBI di 2018. Angka maximum berbilang 9,277 yang didapati PT. SIDO di 2015, sedangkan angka meanCR industri barang konsumsi adalah 2,93118 dengan std deviation sebesar 1,916194.

3. DAR $\left(\mathrm{X}_{3}\right)$ memiliki sampel sebanyak 130, dengan angka minimum berbilang 0,071 yang didapati PT.SIDO di 2015. Angka maximum berbilang 0,744 yang didapati PT.UNVR di 2019, sedangkan angka mean DAR industri barang konsumsi adalah 0,36636 dengan std deviation sebesar 0,174405 .

4. ROE (Y) memiliki sampel sebanyak 130, dengan angka minimum berbilang 0,019 yang didapati PT. BUD di 2015. Angka maximum berbilang 2,245 yang didapati PT.MERK di 2018, sedangkan angka mean ROE industri barang konsumsi adalah 0,24633 dengan std deviation sebesar 0,339384 .

\section{Hasil Uji Asumsi Klasik}

Pengujian Normalitas

Pengujian normalitas bertujuan menyelidiki apakah dalam model regresi, variabel pengganggu ataupun residual berdistribusi dengan baik.

1. Analisis Grafik

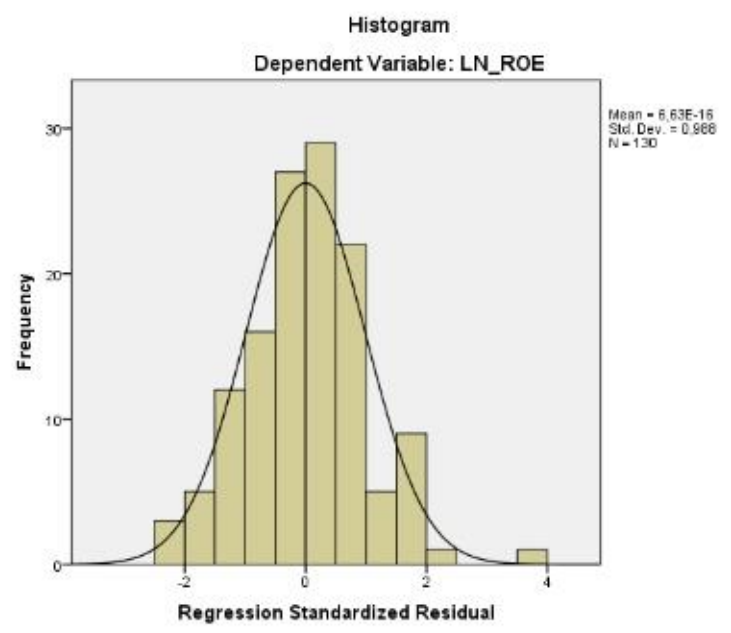

Gambar 1. Analisi Grafik Histogram Setelah Tranformasi 
Dari Gambar 1 boleh dinyatakan kalau pendistribusian data residual bersifat normal. Hal ini terlihat pada kurva yang berupa seperti lonceng.

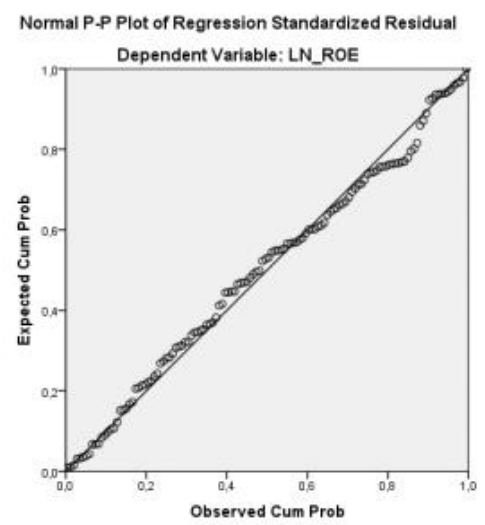

Gambar 2. Analisis Normal Probability Plot Setelah Transformasi

Dari Gambar 2 menunjukkan hasil uji normalitas menggunakan kolmogorov-smirnov dengan nilai signifikansi 0,484 > 0,05 yang maknanya data berdistribusi normal.

2. Analisis Statistik

Hasil dari uji Kolmogorov-Smirnov merupakan uji statistik lain yang dipakai dalam riset ini. Berikut merupakan hasil dari Uji Kolmogorov-Smirnov:

Tabel 3.Uji Normalitas Kolmogorov-Smirnov Test Setelah Tranformasi

One-Sample Kolmogorov-Smirnov Test

\begin{tabular}{llr}
\hline & & Unstandardized Residual \\
\hline $\mathrm{N}$ & & 130 \\
Normal Parameters, & Mean & $0 \mathrm{E}-7$ \\
& Std. Deviation &, 82351993 \\
& Absolute &, 073 \\
Most Extreme Differences & Positive &, 073 \\
& Negative &,- 051 \\
Kolmogorov-Smirnov Z & &, 838 \\
Asymp. Sig. (2-tailed) & &, 484 \\
\hline
\end{tabular}

a. Test distribution is Normal.

b. Calculated from data.

Dari Tabel 3 menyatakan hasil uji normalitas menggunakan kolmogorov-smirnov dengan nilai signifikansi $0,484>0,05$ yang artinya data berdistribusi normal.

\section{Pengujian Multikolonieritas}

Pengujian multikolonieritas memiliki tujuan menyelidiki apakah model regresi mengandung adanya korelasi antara variabel bebas.

Tabel 4.Uji Multikolonieritas Setelah Tranformasi

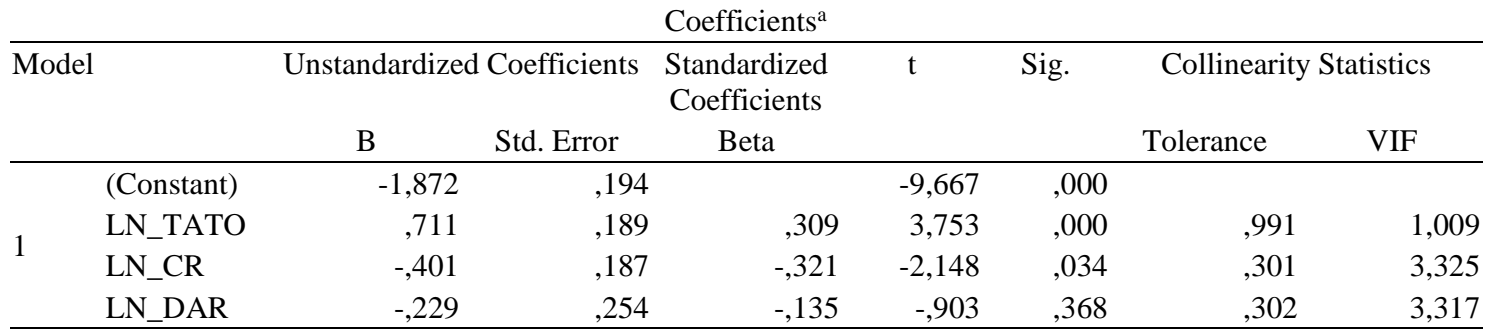

a. Dependent Variable: LN_ROE 
Pada Tabel 4 ditemukan bahwasanya jumlah tolerance yang diperoleh dari TATO adalah 0,991, variabel Rasio Lancar 0,301 dan variabel DAR 0,302. Jumlah VIF TATO adalah 1,009, Rasio Lancar 3,325 dan DAR 3,317. Dari hasil tersebut dapat dinyatakan bahwa tidak terdapat multikolinieritas antar variabel bebas dalam model regresi.

\section{Pengujian Autokorelasi}

Pengujian autokorelasi memiliki tujuan buat mengenali terdapat ataupun tidaknya autokorelasi dalam sesuatu model pengkajian bisa dinilai dengan durbin watson.

Tabel 5.Uji Autokorelasi Setelah Transformasi

Model Summary ${ }^{\mathrm{b}}$

\begin{tabular}{lrrrrr}
\hline Model & R & R Square & Adjusted R Square & Std. Error of the Estimate & \multicolumn{1}{c}{ Durbin-Watson } \\
\hline 1 &, $395^{\mathrm{a}}$ &, 156 &, 136 &, 83327 & 1,943 \\
\hline
\end{tabular}

a. Predictors: (Constant), LN_DAR, LN_TATO, LN_CR

b. Dependent Variable: LN_ROE

Dari Tabel 5 dapat dilihat bahwa hasil uji autokorelasi dengan Durbin Watson sebesar 1,943. Nilai du $<\mathrm{dw}<4-$ du adalah $1,7610<1,943<2,239$. Dari hasil tersebut disimpulkan bahwa tidak terjadinya autokorelasi.

\section{Pengujian Heteroskedastisitas}

Pengujian heteroskedastisitas memiliki tujuan untuk mengetahui apakah terdapat perbedaan residual dari satu observasi ke observasi lainnya dalam model regresi. Ada beberapa cara untuk menguji heteroskedastisitas, diantaranya sebagai berikut:

1. Uji Glejser

Tabel 6.Uji Glejser Setelah Transformasi

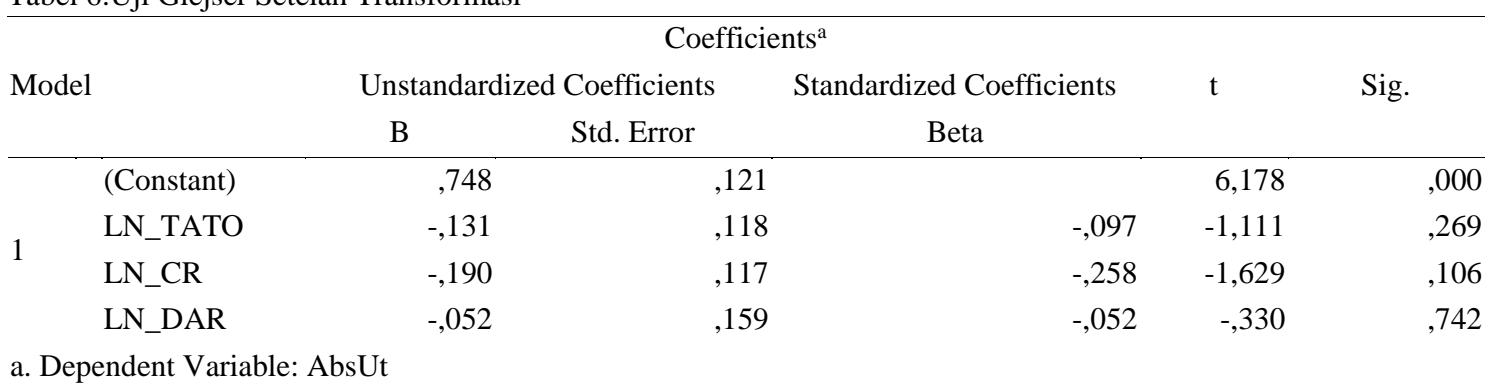

Dari Tabel 6 dapat terlihat bahwa nilai signifikan dari 3 variabel independen TATO sebesar 0,269, Rasio Lancar sebesar 0,106 dan DAR sebesar 0,742 $\geq 0,05$. Dari hasil tersebut dapat dikatakan bahwasanya tidak terjadinya heteroskedastisitas.

2. Analisis Grafik Scatterplot

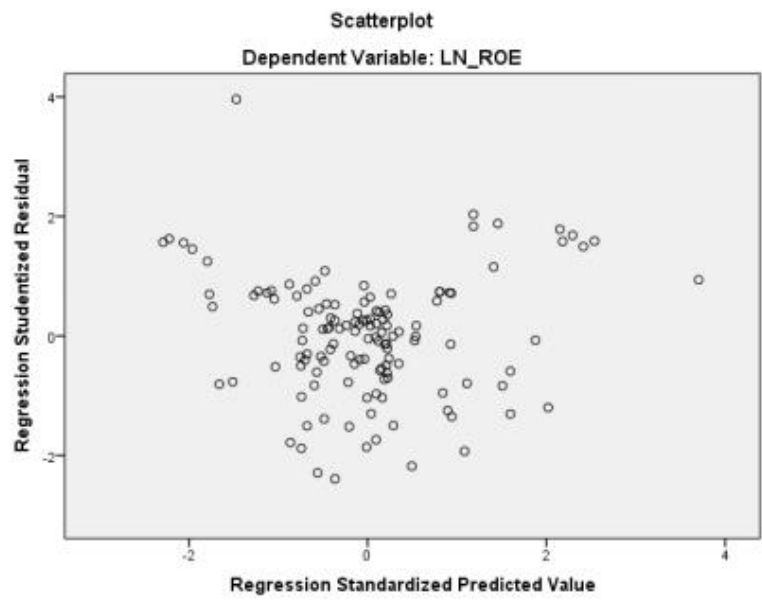

Gambar 3. Analisis Grafik Scatterplot Setelah Transformasi 
Dari Gambar 3 grafik scatterplot terlihat bulatan memencar dengan teratur dan tidak bersatu. Sehingga dari grafik scatterplot dapat dinyatakan bahwa tidak terjadinya heterokedastisitas.

\section{Hasil Analisis Data}

Model Penelitian

Adapun hasil analisis regresi linier berganda adalah:

Tabel 6.Uji Analisis Regresi Linear Berganda

\begin{tabular}{|c|c|c|c|c|c|c|c|c|}
\hline \multirow{3}{*}{\multicolumn{2}{|c|}{ Model }} & \multicolumn{4}{|c|}{ Coefficients $^{\mathrm{a}}$} & \multirow{3}{*}{ Sig. } & & \\
\hline & & \multicolumn{2}{|c|}{ Unstandardized Coefficients } & \multirow{2}{*}{$\begin{array}{c}\text { Standardized } \\
\text { Coefficients } \\
\text { Beta }\end{array}$} & \multirow[t]{2}{*}{$\mathrm{t}$} & & \multicolumn{2}{|c|}{ Collinearity Statistics } \\
\hline & & B & Std. Error & & & & Tolerance & VIF \\
\hline \multirow{4}{*}{1} & (Constant) & $-1,872$ & ,194 & & $-9,667$ &, 000 & & \\
\hline & LN_TATO &, 711 & , 189 & ,309 & 3,753 & 000 & ,991 & 1,009 \\
\hline & LN_CR &,- 401 &, 187 &,- 321 & $-2,148$ &, 034 &, 301 & 3,325 \\
\hline & LN_DAR &,- 229 & 254 &,- 135 &,- 903 & ,368 & ,302 & 3,317 \\
\hline
\end{tabular}

a. Dependent Variable: LN_ROE

Pada tabel 6 persamaan linear berganda pada penelitian ini adalah:

LN ROE $=-1,872+0,711 \mathrm{LN}$ TATO $-0,401 \mathrm{LN} \mathrm{CR}-0,229 \mathrm{LN}$ DAR

Penjelasan:

1. Jumlah koefisien TATO $\left(\mathrm{X}_{1}\right)$ adalah $+0,711$ menerangkan bahwasanya setiap penambahan TATO 1 satuan akan disertai kenaikan ROE sejumlah 0,711 satuan.

2. Jumlah koefisien CR $\left(\mathrm{X}_{2}\right)$ adalah - 0,401, menerangkan bahwasanya setiap penambahan CR 1 satuan akan menyebabkan penurunan ROE sejumlah 0,401 satuan.

3. Jumlah koefisien DAR $\left(\mathrm{X}_{3}\right)$ adalah - ,0,229, menerangkan bahwasanya setiap penambahan DAR1 satuan akan mengakibatkan penurunan ROE sejumlah 0,229 satuan.

\section{Koefisien Determinasi}

Koefisien determinasi memiliki tujuan untuk mengenali seberapa peluang keahlian untuk menerangkan variabel terikat. Semakin besar $\left(\mathrm{R}^{2}\right)$, maka bisa disimpulkan bahwasanya kemampuan variabel leluasa adalah besar terhadap variabel terikat. Hasil dari $\mathrm{R}^{2}$ adalah:

Tabel 7.Koefisien Determinasi

\begin{tabular}{|c|c|c|c|c|c|}
\hline \multicolumn{6}{|c|}{ Model Summary ${ }^{\mathrm{b}}$} \\
\hline Model & $\mathrm{R}$ & R Square & Adjusted R Square & Std. Error of the Estimate & Durbin-Watson \\
\hline 1 & $395^{\mathrm{a}}$ & , 156 & 136, & ,83327 & 1,943 \\
\hline
\end{tabular}

a. Predictors: (Constant), LN_DAR, LN_TATO, LN_CR

b. Dependent Variable: LN_ROE

Dari tabel 7 ditemukan hasil adjusted $R$ square 0,136 ataupun 13,6 persen dari variasi variabel dependen ROE yang dapat dijelaskan oleh variabel independen TATO, CR, DAR sedangkan 86,4 persen dijelaskan variabel lain diluar penelitian ini.

\section{Uji Hipotesis Dengan Simultan (Uji F)}

Uji $\mathrm{F}$ memiliki tujuan menerangkan apakah variabel $\mathrm{X}_{1}, \mathrm{X}_{2}, \mathrm{X}_{3}$ memiliki dampak terhadap variabel Y.

Tabel 8.Uji F Secara Simultan

\begin{tabular}{rllllll}
\multicolumn{7}{c}{ ANOVA $^{\mathrm{a}}$} \\
\hline \multicolumn{1}{l}{ Model } & Sum of Squares & $\mathrm{df}$ & Mean Square & F & Sig. \\
\hline \multirow{2}{*}{1} & Regression & 16,164 & 3 & 5,388 & 7,760 &, $000^{\mathrm{b}}$ \\
& Residual & 87,486 & 126 &, 694 & \\
& Total & 103,650 & 129 & & \\
\hline
\end{tabular}

a. Dependent Variable: LN_ROE

b. Predictors: (Constant), LN_DAR, LN_TATO, LN_CR 
Pada tabel 8 hasil $\mathrm{F}_{\text {hitung }}$ adalah 7,760 dengan menggunakan tabel $\mathrm{F}$ maka $\mathrm{df}_{1}=\mathrm{k}=3$ dan $\mathrm{df}_{2}=130-3-1=126$ dengan $\mathrm{F}_{\text {tabel }} 2,68$ maka hasilnya adalah $\mathrm{F}_{\text {hitung }}>\mathrm{F}_{\text {tabel }}(7,760>2,68)$. Nilai sig $0,000<0,05$ yang berarti secara simultan TATO, CR, DAR memiliki pengaruh dan signifikan atas ROE pada consumer goods industry di BEI 2015-2019.

\section{Uji Hipotesis Dengan Parsial (Uji t)}

Uji t secara parsial bertujuan buat menganalisa dampak setiap variabel bebas dengan tingkat signifikansi 0,05 pada ROE.

Tabel 9.Uji t Secara Parsial

\begin{tabular}{|c|c|c|c|c|c|c|c|c|}
\hline \multirow{3}{*}{\multicolumn{2}{|c|}{$\overline{\text { Model }}$}} & \multirow{2}{*}{\multicolumn{2}{|c|}{$\begin{array}{l}\text { Unstandardized } \\
\text { Coefficients }\end{array}$}} & \multicolumn{5}{|l|}{ Coefficients $\mathrm{s}^{\mathrm{a}}$} \\
\hline & & & & \multirow{2}{*}{$\begin{array}{c}\text { Standardized } \\
\text { Coefficients } \\
\text { Beta }\end{array}$} & \multirow[t]{2}{*}{$\mathrm{t}$} & \multirow[t]{2}{*}{ Sig. } & \multicolumn{2}{|c|}{ Collinearity Statistics } \\
\hline & & $\mathrm{B}$ & Std. Error & & & & Tolerance & VIF \\
\hline \multirow{4}{*}{1} & (Constant) & $-1,872$ & ,194 & & $-9,667$ & ,000 & & \\
\hline & LN_TATO &, 711 & , 189 & ,309 & 3,753 & ,000 & 991 & 1,009 \\
\hline & LN_CR &,- 401 & 187 &,- 321 & $-2,148$ & 034 & ,301 & 3,325 \\
\hline & LN_DAR &,- 229 & 254 &,- 135 &,- 903 & ,368 & ,302 & 3,317 \\
\hline
\end{tabular}

a. Dependent Variable: LN_ROE

Dari tabel 9 nilai $t_{\text {tabel }}$ peluang 0,05 pada derajat kebebasan $(n-k-1=130-3-1=126)$ ialah 1,97897. Hasil uji t adalah:

1. TATO cara parsial didapat dari hasil thitung 3,753 dengan hasil significant 0,000 . Hasil $\mathrm{t}_{\text {hitung }} \geq \mathrm{t}_{\text {tabel }}(3,753 \geq 1,97897)$ dan hasil significant $(0,000 \leq 0,05)$ artinya TATO memiliki pengaruh signifikan atas ROEpada consumer goods industry di BEI 20152019.

2. CR cara parsial didapat dari hasil thitung $-2,148$ dengan hasil significant 0,034 . Hasil $\mathrm{t}_{\text {hitung }} \leq \mathrm{t}_{\text {tabel }}(-2,148 \leq 1,97897)$ dan hasil significant $(0,034 \leq 0,05)$ artinya CR tidak memiliki pengaruh signifikan atas ROEpada consumer goods industry di BEI 20152019.

3. DARcara parsial didapat dari hasil $t_{\text {hitung }}-0,903$ dengan hasil significant 0,368 . Hasil $\mathrm{t}_{\text {hitung }} \leq \mathrm{t}_{\text {tabel }}(-0,903 \leq 1,97897)$ dan hasil significant $(0,368 \geq 0,05)$ artinya DAR tidak memiliki pengaruh signifikan atas ROEpada consumer goods industry di BEI 20152019.

\section{Pembahasan}

\section{TATO Terhadap ROE}

Berdasarkan hasil penelitian cara parsial yang didapat hasil $t_{\text {hitung }} 3,753$ beserta hasil significant 0,000 . Hasil $\mathrm{t}_{\text {hitung }} \geq \mathrm{t}_{\text {tabel }}(3,753 \geq 1,97897)$ dan hasil significant $(0,000 \leq 0,05)$ artinya TATO memiliki pengaruh signifikan terhadap ROE. Hasil penelitian sejalan dengan pendapat Jessica et al. (2019), "semakin tinggi rasio ini menunjukkanbahwa asset yang dikelolaoleh perusahaan sangat sangat kondusif guna meningkatkan kegiatan penjualan untuk menghasilkan keuntungan. Situasi tersebut menjelaskan bahwasanya tingkat perputaran total asset berpengaruh positif bagi profitabilitas".

\section{CR Terhadap ROE}

Berdasarkan hasil penelitian cara parsial yang didapat hasil $t_{\text {hitung }}-2,148$ berserta nilai significant 0,034 . Hasil $\mathrm{t}_{\text {hitung }} \leq \mathrm{t}_{\text {tabel }}(-2,148 \leq 1,97897)$ dan hasil significant $(0,034 \leq 0,05)$ artinya CR tidak memiliki pengaruh signifikan terhadap ROE. Hasil penelitian sejalan dengan pendapat Pongrangga, et al. (2015), "semakin besar rasio lancar terhadap kewajiban jangka pendek, semakin besar efektivitas dalam menutupi ataupun membayar semua kewajiban jangka 


\section{DAR Terhadap ROE}

Berdasarkan hasil penelitian cara parsial yang didapat hasil $t_{\text {hitung }}-0,903$ berserta nilai significant 0,368 . Hasil $\mathrm{t}_{\text {hitung }}<\mathrm{t}_{\text {tabel }}(-0,903 \leq 1,97897)$ dan hasil significant $(0,368 \geq 0,05)$ artinya DAR tidak memiliki pengaruh signifikan terhadap ROE. Hasil penelitian sejalan dengan pendapat Kasmir (2016), bila rasionya besar berarti pendanaan dengan hutang terus menjadi bertambah, situasi tersebut menyebabkan perusahaan kesulitan dalam mendapatkan pinjaman tambahan sebab diperkirakan keuangan perusahaan tidak memadai untuk melunasi hutang dengan asset-asetnya".

\section{KESIMPULAN}

Berdasar pada hasil, dapat disimpulkan bahwa secara simultan menerangkan bahwa TATO, CR, dan DAR memiliki pengaruh serta signifikan atas ROE pada consumer goods industry di BEI 2015-2019 sedangkan secara parsial menerangkan bahwa TATO memiliki pengaruh signifikan atas ROE pada consumer goods industry di BEI 2015-2019, CR tidak memiliki pengaruh signifikan atas ROE pada consumer goods industry di BEI 2015-2019, DAR tidak memiliki pengaruh signifikan atas ROE pada consumer goods industry di BEI 2015-2019.

\section{DAFTAR PUSTAKA}

Ghozali, \& H.Imam. (2016). Aplikasi Analisis Multivariete Dengan Program IBM SPSS 23. Ed 8. Semarang: Badan Penerbit Universitas Diponegoro.

Hamli, S. (2014). Buku Praktis Akuntansi Biaya \& Keuangan. Jakarta: Laskar Aksara.

Harahap, \& Sofyan, S. (2015). Analisis Kritis Atas Laporan Keuangan. Cetakan Keduabelas. Jakarta: PT RajaGrafindo Persada.

Hery. (2018). Analisis Laporan Keuangan. Cetakan pertama. Jakarta: PT Gramedia.

Irham, F. (2017). Analisis Laporan Keuangan. Bandung: Alfabeta.

Jessica, et al. (2019). Pengaruh ITO, CR, DER, TATO \& WCTO Terhadap ROE Pada Perusahaan Aneka Industri Terdaftar di BEI. Berkala Akuntansi Keuangan Indonesia, 4(2), 43-60.

Kasmir. (2016). Analisis Laporan Keuangan. Cetakan Kesembilan. Jakarta: PT Raja Grafindo Persada.

Pongrangga, et al. (2015). Pengaruh Current Ratio, Total Asset Turnover \& Debt To Equity Ratio Terhadap Return On Equity (Studi Pada Perusahaan Sub Sektor Property dan Real Estate Yang Terdaftar di BEI Periode 2011-2014). Jurnal Administrasi Bisnis, 25(2).

Sugiyono. (2015). Metode Penelitian Kuantitatif, Kualitatif, dan R\&D. Bandung: CV Alfabeta. Sukmawati, S. (2019). Analisis Laporan Keuangan. Ed 1. Yogyakarta: Andi Offset.

Sulindawati, Yuniarta \& Purnamawati. (2018). Manajemen Keuangan Sebagai Dasar Pengambilan Keputusan Bisnis. Cetakan Kedua. Depok: Kharisma Putra Utama Offset

Syahyunan. (2013). Manajemen Keuangan 1 (Perencanaan, Analisis \& Pengendalian Keuangan). Ed 2. Medan: USU Press.

Werner, R. M. (2013). Analisis Laporan Keuangan Proyeksi Dan Valuasi Saham. Jakarta: Salemba Empat. 